\title{
Utilizing pioneer species as a hydrological nurse crop to lower water table for reforestation of poorly drained boreal sites
}

\author{
Simon M. LANDHÄUSSER*, Victor J. LIEFFERS, Uldis SILINS \\ Centre for Enhanced Forest Management, Department of Renewable Resources, University of Alberta, Edmonton, Alberta, T6G 2E3, Canada
}

(Received 24 June 2002; accepted 10 February 2003)

\begin{abstract}
On cold and wet sites in the boreal forest, high water table and anaerobic soil conditions limit the establishment of planted white spruce. In a controlled-environment experiment we determined physiological and morphological responses of a grass Calamagrostis canadensis and two shrubs Salix planifolia and Alnus crispa to water table and soil temperature and evaluated their capacity to lower the water table on wet sites. All three species tended to grow better at the warmer soil temperatures and imperfectly drained treatments but $C$. canadensis actually developed the greatest leaf area in the near saturated conditions. Similarly, C. canadensis and A. crispa had greatest transpiration rates in the imperfectly drained and warm soil treatments. In contrast, $S$. planifolia had the greatest transpiration at $5{ }^{\circ} \mathrm{C}$ soils. We suggest that $C$. canadensis is suitable as a hydrological nurse species on these wet sites, but in light of its competitive nature, the shrubs particularly $S$. planifolia would be preferable.
\end{abstract}

competition / flooding / regeneration / soil temperature / water-use

Résumé - Utilisation d'espèces pionnières susceptibles de jouer un rôle hydrologique en abaissant le niveau du plan d'eau pour faciliter le boisement de stations boréales mal drainées. Dans les stations froides et humides de la forêt boréale, le haut niveau du plan d'eau et les conditions d'anaérobie du sol sont défavorables au reboisement en épicéa blanc. Une expérimentation en milieu contrôlé a permis de déterminer les réponses physiologiques et morphologiques d'une espèce herbacée Calamagrostis canadensis et de deux arbustes, Salix planifolia et Alnus crispa, au niveau du plan d'eau et à la température du sol, et d'évaluer leur capacité à abaisser le niveau du plan d'eau sur stations humides. Les trois espèces tendent à mieux se développer avec les traitements où la température du sol est plus élevée avec drainage médiocre ; mais $C$. canadensis présente un développement de surface foliaire nettement plus grand dans des conditions de sol proches de la saturation. De même, pour $C$. canadensis et A. crispa on enregistre les taux de transpiration les plus élevés pour les traitements sol chaud et drainage médiocre. Par contre, S. planifolia manifeste un maximum de transpiration avec une température du sol de $5^{\circ} \mathrm{C}$. Nous suggérons que $C$. canadensis peut jouer le rôle d'espèce nurse hydrologique sur ces stations humides ; mais compte tenu des problèmes de concurrence, on devrait préférer les arbustes, et en particulier $S$. planifolia.

concurrence / inondation / régénération / température du sol / utilisation de l'eau

\section{INTRODUCTION}

One of the most difficult stand and site types to regenerate in the western boreal forest of North America are white spruce (Picea glauca (Moench) Voss) stands on subhygric to hygric sites $[12,41]$. There are three major reasons for the difficulty in regenerating these sites.

Firstly, after harvesting, most of the transpiring leaf area is removed, the ground water tables rise and soil becomes waterlogged $[9,19,21]$. The high water table results in poor aeration of the rooting zones for the establishing trees [26]. Since none of the northern conifer species have particularly strong mechanisms to withstand anaerobic conditions [6], flooding usually results in slow growth rates or mortality of establishing spruce trees [42].

Secondly as a result of the cold climate and high soil moisture content, there is build-up of insulating organic matter on the soil surface which slows time of spring thaw and depresses soil temperatures during the summer $[3,20]$. Cold soils are noted to depress shoot and leaf growth $[31,35]$, water uptake and root growth [15-18, 25, 59] and photosynthesis [7, 14, 16, $48,54,55,59]$ in many boreal tree species.

Thirdly, in the first few years after logging these sites are quickly invaded by competing vegetation such as marsh reed grass (Calamagrostis canadensis (Michx.) Beauv.), and slightly later, tall shrubs (Alnus spp. and Salix spp.) dominate

\footnotetext{
*Corresponding author: Simon.Landhausser@ualberta.ca
} 
$[5,24,32,44]$. All of these species may be strong competitors for light and nutrients with $P$. glauca $[5,24]$. However, $C$. canadensis can be viewed as a more serious "competitor" than the shrubs for newly planted conifer seedlings. The persistent litter formed by this grass can also kill small trees by snow press and insulates the soil and prevents soil warming in spring, and can shade conifer seedlings all year long [8, 13, 21, 44]. In contrast, deciduous shrubs during their leaf-off period in the spring and fall, will allow for periods of strong photosynthesis in juvenile spruce [45]. Thus tall shrubs are likely much more benign competitors than the grass. In addition, the taller shrubs might also aid in the suppression of $C$. canadensis by reducing the light levels sufficiently to create unfavorable conditions for its growth [43, 60].

Current vegetation management practices on these productive sites attempt to eliminate all competitors. This, however, may actually cause a more serious problem for the regenerating $P$. glauca seedlings as the removal of these pioneers would tend to increase the amount of or prolong the period of soil waterlogging. Objectives of this study were to test the transpiration and water use of $C$. canadensis, Alnus crispa (Ait.) Pursh, and Salix planifolia Pursh under nearly saturated and partially drained soils. We also tested their ability to grow and transpire water under warm and cold soil conditions. Considerable research has explored the effects of soil temperature (e.g. [16, 25, 33, 35, 54]) or flooding stress (e.g. [22, 27, 28, 56]) on plant physiology and growth in a wide variety of species but the combined effect of these to factors has received little attention $[4,42]$. This knowledge will allow us to rank these species according to their ability to grow under wet and cold conditions and assess their potential as a hydrological nurse species to reduce the high water table of these subhygric to hygric boreal forest sites. Nurse crops are known to have beneficial effects by providing shelter and improving nutrient supply for crop tree species [36, 37, 53]; however there is little information on the benefit of nurse species for lowering high water tables.

\section{MATERIALS AND METHODS}

\subsection{Plant material and growth conditions}

Seedlings used in this study were grown from seeds which were collected locally on subhygric to hygric sites in north-central Alberta, Canada. Seedlings of the grass Calamagrostis canadensis and the common shrub species Alnus crispa and Salix planifolia were established and grown in containers (styro blocks $6 \mathrm{~cm}$ in diameter and $15 \mathrm{~cm}$ deep) for one growing season. The growth chamber conditions were 20 hours light and 4 hours dark cycle, an air temperature (day/ night) $18{ }^{\circ} \mathrm{C} / 16^{\circ} \mathrm{C}, 60 \%$ relative humidity, and $400 \mu \mathrm{mol} \mathrm{m} \mathrm{m}^{-2} \mathrm{~s}^{-1}$ photosynthetically active radiation (PAR) at the seedling level. After three months of growth, seedlings were hardened by reducing air temperature and light, watering, and nutrition levels. After one month seedlings were transferred to a walk-in cooler and chilled at $0{ }^{\circ} \mathrm{C}$ for one more month. This technique has been successfully used to complete bud development and allow seedlings to reflush [33]. Alnus crispa seedlings used for the experiment were on average $8.8 \mathrm{~cm}$ tall and had a root collar diameter of $2.5 \mathrm{~mm}, S$. planifolia seedlings were $12.5 \mathrm{~cm}$ tall and had a calliper of $2.5 \mathrm{~mm}$, and C. canadensis had initial dry weights of $3.5 \mathrm{~g}$ of above ground and $1.3 \mathrm{~g}$ below ground biomass.
Forty-two dormant seedlings of each of the three species were selected and subjected to three soil temperatures $\left(5,10\right.$ and $\left.20^{\circ} \mathrm{C}\right)$ and two water tables (12 and $25 \mathrm{~cm}$ from the soil surface) $(n=7)$. Growing containers consisted of two PVC pipes, sealed at one end, which were connected at the bottom with a hose $(1 \mathrm{~cm}$ diameter $)$ allowing movement of water between pipes. One pipe $(33 \mathrm{~cm}$ long $15.2 \mathrm{~cm}$ diameter) held the seedlings and the planting medium (sandpeat $3: 1 \mathrm{v} / \mathrm{v}$ ) while the second pipe $(33 \mathrm{~cm}$ long and $5.1 \mathrm{~cm}$ diameter) served as a water reservoir to maintain constant water levels.

The water reservoir was sealed at the top with a rubber stopper with a small plastic tube through the centre of the stopper. When tightly sealed, the bottom of the tube in the reservoir pipe established the constant water level in the plant pipe which maintained the water level regardless of daily water use by the seedling. The reservoir was periodically refilled to a marked level by tightly clamping the hose connection between the two pipes before removing the stopper/tube assembly. Filling the reservoir to the marker allowed for the determination of evapotranspiration rates at the pot level. After refilling the reservoir, the rubber stopper was put back into place and the hose connection was unclamped. To estimate evaporation rates from the soil surface during the experimental period, pots without plants (control) were included.

To control soil temperature, the pots were submerged into water baths $\left(5,10\right.$ and $\left.20^{\circ} \mathrm{C}\right)$ consisting of watertight boxes $(90 \times 90 \times 46 \mathrm{~cm})$ similar to the design used by Landhäusser and Lieffers [31]. The plants were fertilised once a week with $2 \mathrm{~g} \mathrm{~L}^{-1}$ of a commercial fertilizer (20-20-20 N-P-K with chelated micronutrients). Growth chamber conditions were the same as described above. During the growing period, the pots were moved to different locations within the chamber to compensate for possible spatial differences in growth chamber conditions.

After six weeks, water-use on a whole pot basis was determined in the pots containing plants and in the control pots over a period of ten days, by regularly refilling the reservoir pipe with water to a constant mark with a graduated syringe. Water-use of the whole seedling was determined by subtracting the water loss in the control pots from the water loss of the pots containing plants.

After water-use was determined over the ten day period, the experiment was terminated and physiological and growth variables were measured on all seedlings ( $n=7$ for each treatment combination). Gas exchange was measured on fully expanded leaves of the actively growing seedlings and with an open-system infrared gas analyser (IRGA, CIRAS I, PP Systems, Haverhill, Mass.) over two days between hour 5 and 13 of the light cycle. In the cuvette, light was maintained at $1000 \mu \mathrm{mol} \mathrm{m}-2 \mathrm{~s}^{-1}$ (PAR), leaf temperature at $20^{\circ} \mathrm{C}$, and relative humidity at $35 \%$. Projected leaf area was used to calculate the physiological variables. Total projected leaf area of the two shrub species was measured with a leaf area meter (LI-3100, Li-Cor Ltd. Lincoln, NE, USA), while total projected leaf area of $C$. canadensis was estimated using a relationship between leaf dry mass and projected leaf area of subsamples measured with a computer scanner and imaging software (Sigma Scan 3.0, Jandel Scientific, San Rafael, CA, USA).

Soil oxygen diffusion rates (ODR) were measured at 3- 8- and $15-\mathrm{cm}$ depths in all pots from the ground surface using the platinum microelectrode method [40]. Polarograms (amperage-voltage curves) were generated for each electrode in control pots to determine the appropriate voltage for ODR measurements [46]. The voltage was applied in $0.1 \mathrm{~V}$ increments from 0.1 to $0.9 \mathrm{~V}$. and a clear plateau in the polarograms was observed between 0.4 and $0.7 \mathrm{~V}$. A constant applied voltage of $0.55 \mathrm{~V}$ was selected for ODR measurements and the current was read after $3 \mathrm{~min}$ and ODR (mass $\mathrm{O}_{2} \mathrm{~L}^{-2} \mathrm{~T}^{-1}$ ) was calculated from measured current $(\mathrm{mA})$ and platinum electrode surface area after Letey and Stolzy [40]. 
After the physiological measurements were taken, leader length, root collar diameter, and dry mass of roots, old and new shoots and leaves were measured for all seedlings. Leaf weight ratios (LWR $\mathrm{g}_{\text {leaf }} \mathrm{g}^{-1}$ plant $)$ were calculated.

All response variables were analyzed as a randomized $3 \times 2$ factorial design with 3 soil temperatures $\left(5,10\right.$, and $\left.20^{\circ} \mathrm{C}\right)$ and 2 water tables $(12$ and $25 \mathrm{~cm})$ and as fixed main effects. To test for treatment effects, analysis of variance procedures and least significant difference multiple comparisons were performed with general linear models. Only qualitative comparisons of response strategies to soil temperature and flooding were made among the three species. All response variables met the assumption of normal distribution and homogeneity of variances. To test for treatment effects, analysis of variance procedures and least significant difference multiple comparisons were performed with general linear models available in SAS 6.11 (SAS Institute Inc., Cary, NC). The significance levels were set at $\alpha=0.05$.

\section{RESULTS}

\subsection{Oxygen diffusion rates (ODR) and soil evaporation rates}

Mean (three depths) oxygen diffusion rates (ODR) at the low water tables (imperfectly drained) were $14.2 \times 10^{-8} \mathrm{~g}$ $\mathrm{O}_{2} \mathrm{~cm}^{-2} \mathrm{~min}^{-1}$ compared to $3.0 \times 10^{-8} \mathrm{~g} \mathrm{O}_{2} \mathrm{~cm}^{-2} \mathrm{~min}^{-1}$ at the high water table (nearly flooded) $(p<0.001)$. Overall, soil temperature did not have a significant effect on ODR $(p=0.681)$. Calamagrostis canadensis tended to have much lower ODR values in the pots than the other two species; this was especially evident at greater depth. At a depth of $15 \mathrm{~cm}$, ODR in C. canadensis was $0.06 \times 10^{-8} \mathrm{~g} \mathrm{O}_{2} \mathrm{~cm}^{-2} \mathrm{~min}^{-1}$ compared with 0.37 and $0.48 \times 10^{-8} \mathrm{~g} \mathrm{O}_{2} \mathrm{~cm}^{-2} \mathrm{~min}^{-1}$ for $A$. crispa and $S$. planifolia, respectively. Evaporation rates from the soil surface of the control pots increased with increasing soil temperatures $(p<0.001)$. Depth to water table influenced evaporation only at a soil temperature of $20{ }^{\circ} \mathrm{C}$ where evaporation rates were $11.2 \mathrm{~mL} \mathrm{~d}^{-1}$ at the high water tables compared with $7.4 \mathrm{~mL} \mathrm{~d}^{-1}$ at the low water table; this resulted in a significant soil temperature $\times$ water table interaction $(p=0.005)$. Over both water tables, an average of 1.3 ( $\pm 0.8 \mathrm{SD}), 2.8$ ( $\pm 1.5 \mathrm{SD})$, and $9.3( \pm 2.3 \mathrm{SD}) \mathrm{mL}$ of water evaporated per day at soil temperatures of 5,10 , and $20{ }^{\circ} \mathrm{C}$, respectively.

\subsection{Physiological variables and water-use}

In all three species, the high water table $(12 \mathrm{~cm}$ from soil surface) resulted in overall low transpiration rates measured at the leaf level ( $E$, IRGA measurements); however, only $S$. planifolia showed a significant increase in $E$ when the water table was lowered to a depth of $25 \mathrm{~cm}(p=0.033)$ (Fig. 1). Higher soil temperatures resulted in higher transpiration rates $(E)$ in $C$. canadensis, where $E$ increased by $65 \%$ from $0.82 \mathrm{mmol} \mathrm{m}^{-2} \mathrm{~s}^{-1}$ at a soil temperature of $5^{\circ} \mathrm{C}$, to $1.36 \mathrm{mmol} \mathrm{m}^{-2} \mathrm{~s}^{-1}$ at $10{ }^{\circ} \mathrm{C}$ $(p=0.005)$. This is in contrast to $S$. planifolia where the higher soil temperatures resulted in a reduction of $E$ from $2.26 \mathrm{mmol} \mathrm{m}^{-2} \mathrm{~s}^{-1}$ at $5^{\circ} \mathrm{C}$ to $1.48 \mathrm{mmol} \mathrm{m}^{-2} \mathrm{~s}^{-1}$ at 10 and $20{ }^{\circ} \mathrm{C}(p=0.005)$. Soil temperature did not affect $E$ in $A$. crispa $(p=0.408)$ (Fig. 1).
Across all treatments, water-use measured at the pot level and adjusted for leaf area was highest in S. planifolia $(0.49 \mathrm{~mL}$ $\mathrm{cm}^{-2}$ day $^{-1}$ ) followed by $C$. canadensis and $A$. crispa with 0.39 and $0.33 \mathrm{~mL} \mathrm{~cm}^{-2} \mathrm{day}^{-1}$, respectively (Fig. 1). Water-use in S. planifolia was highest at soil temperatures of 5 and $10^{\circ} \mathrm{C}$ $(p=0.043)$ and the low water table treatment $(p=0.015)$. However plant water-use in S. planifolia was not affected by a change in water table when grown at soil temperatures of 5 and $10^{\circ} \mathrm{C}\left(0.053 \mathrm{~mL} \mathrm{~cm}^{-2} \mathrm{day}^{-1}\right)$ but at a soil temperature of $20{ }^{\circ} \mathrm{C}$ where water-use was lower $\left(0.029 \mathrm{~mL} \mathrm{~cm}^{-2} \mathrm{day}^{-1}\right)$ at the high water table compared with the low water table $\left(0.055 \mathrm{~mL} \mathrm{~cm} \mathrm{~cm}^{-2} \mathrm{day}^{-1}\right)$ which resulted in a significant soil temperature $\times$ water table interaction $(p=0.007)$. Water-use in C. canadensis was $0.045 \mathrm{~mL} \mathrm{~cm}^{-2}$ day $^{-1}$ at the low water table compared with $0.035 \mathrm{~mL} \mathrm{~cm}^{-2} \mathrm{day}^{-1}$ at the high water table $(p=0.003)$. Increasing soil temperature from $5^{\circ} \mathrm{C}$ to $10{ }^{\circ} \mathrm{C}$ resulted in an $41 \%$ increase of water-use measured at the pot level, where it increased from 0.029 to $0.041 \mathrm{~mL} \mathrm{~cm}^{-2}$ day $^{-1}(p<0.001)$. There was no further increase in water-use at $20{ }^{\circ} \mathrm{C}(p>0.05)$. Similarly, water-use in A. crispa was lower at $5^{\circ} \mathrm{C}$ soil temperature with $0.030 \mathrm{~mL} \mathrm{~cm}{ }^{-2}$ day $^{-1}$ compared with 0.037 and $0.039 \mathrm{~mL} \mathrm{~cm}^{-2}$ day $^{-1}$ at 10 and $20{ }^{\circ} \mathrm{C}$, respectively $(p=0.047)$. Water-use in $A$. crispa tended to be lower at the high water table compared to the low water table $(p=0.058)$. Differences in treatment means in A. crispa were somewhat weaker likely due to the larger variation among measurements (Fig. 1).

Similarly to water-use, overall net assimilation rates $(N A)$ were the highest in $S$. planifolia with $7.6 \mu \mathrm{mol} \mathrm{m}^{-2} \mathrm{~s}^{-1}$ followed by C. canadensis and A. crispa with 5.8 and $5.3 \mu \mathrm{mol} \mathrm{m} \mathrm{m}^{-2} \mathrm{~s}^{-1}$, respectively (Fig. 1). Net assimilation in S. planifolia was not affected by soil temperature $(p=0.093)$; however, $N A$ was significantly lower at the high water table at soil temperatures of 5 and $20{ }^{\circ} \mathrm{C}$, while at $10^{\circ} \mathrm{C} \mathrm{NA}$ did not differ between the two water tables (soil temperature $\times$ water table $(p=0.031)$ ). The height of the water table did not have an affect on $N A$ in C. canadensis $(p=0.11)$; however, at $5{ }^{\circ} \mathrm{C}$ soil temperature $N A$ was reduced by about $60 \%$ to $3.0 \mu \mathrm{mol} \mathrm{m} \mathrm{m}^{-2} \mathrm{~s}^{-1}$ from 7.5 and $7.0 \mu \mathrm{mol} \mathrm{m} \mathrm{m}^{-2} \mathrm{~s}^{-1}$ at 10 and $20^{\circ} \mathrm{C}$, respectively. In $A$. crispa, NA was $6.4 \mu \mathrm{mol} \mathrm{m} \mathrm{m}^{-2} \mathrm{~s}^{-1}$ at the low water table treatment compared to $4.1 \mu \mathrm{mol} \mathrm{m} \mathrm{m}^{-2} \mathrm{~s}^{-1}$ at the high water table $(p=0.006)$. In contrast to $C$. canadensis, $N A$ in $A$. crispa increased from 4.7 to $7.3 \mu \mathrm{mol} \mathrm{m}{ }^{-2} \mathrm{~s}^{-1}$ only between 10 and $20{ }^{\circ} \mathrm{C}(p=0.003)$ (Fig. 1).

\subsection{Growth variables}

After seven weeks $C$. canadensis had produced significantly greater leaf area $\left(7073 \mathrm{~cm}^{2}\right)$ than $S$. planifolia $\left(331 \mathrm{~cm}^{2}\right)$ and A. crispa $\left(208 \mathrm{~cm}^{2}\right)$ (Fig. 2). All three species attained maximum leaf area at soil temperatures of $20{ }^{\circ} \mathrm{C}$; however, A. crispa and S. planifolia produced the highest leaf area at the low water table. In contrast, $C$. canadensis produced the greatest leaf area in the high water table treatment ( $p=0.004)$. In $A$. crispa an effect of water table was only detectable at a soil temperature of $20{ }^{\circ} \mathrm{C}$ where leaf area increased from $92 \mathrm{~cm}^{2}$ to $208 \mathrm{~cm}^{2}$ when the water table was low $(25 \mathrm{~cm})$ and this resulted in a significant soil temperature $\times$ water table interaction $(p=0.011)$. Soil temperature had a significant effect on leaf area in all three species. Leaf area in 


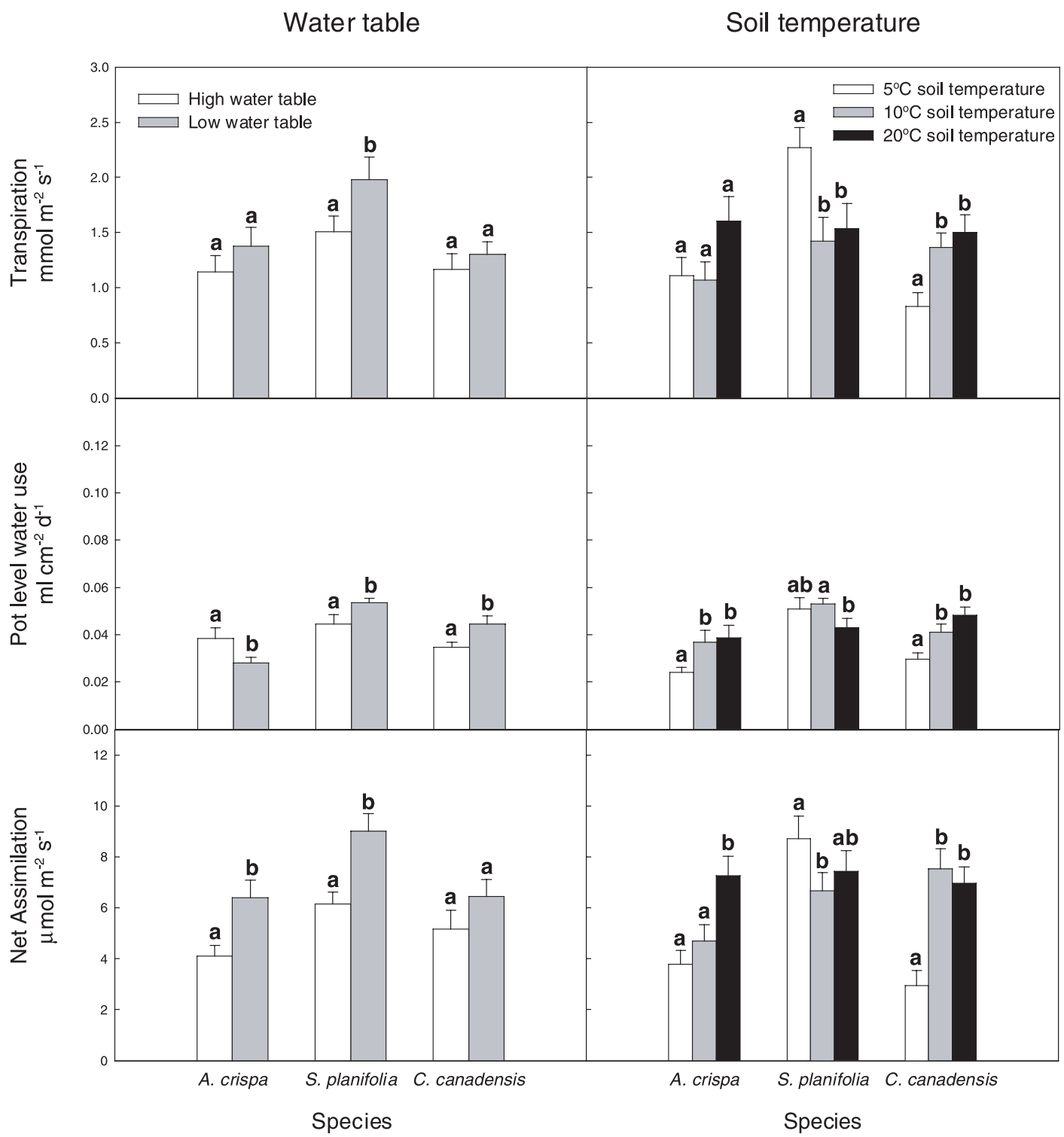

Figure 1. Transpiration, pot level water use, and net assimilation of Alnus crispa, Salix planifolia and Calamagrostis canadensis grown at low water table (imperfectly drained) and high water table (nearly flooded) level and at 5,10 and $20{ }^{\circ} \mathrm{C}$ soil temperatures $(n=7)$. Air temperature was $20^{\circ} \mathrm{C}$. Different letters indicate differences among treatment means within a species.

C. canadensis tripled between 5 and $20^{\circ} \mathrm{C}(p<0.001)$ and approximately doubled in S. planifolia $(p=0.004)$ and $A$. crispa $(p=0.002)$. While total leaf area in $S$. planifolia was similar at $10^{\circ} \mathrm{C}$ and $20^{\circ} \mathrm{C}$, both $C$. canadensis and $A$. crispa had similar leaf area at 5 and $10{ }^{\circ} \mathrm{C}$ but produced more leaf area at $20{ }^{\circ} \mathrm{C}$ (Fig. 2).

Leaf weight ratio (LWR leaf weight over total plant weight) were generally the highest in A. crispa and C. canadensis with $0.51 \mathrm{~g} \mathrm{~g}^{-1}$ while LWR was lower in S. planifolia with $0.4 \mathrm{~g} \mathrm{~g}^{-1}$. In $C$. canadensis, LWR was lower at the low water table compared with the high water table; however at a soil temperature of $10{ }^{\circ} \mathrm{C}$ this reduction was not significant and this resulted in a soil temperature $\times$ water table interaction $(p<0.001)$. While
LWR in A. crispa was not affected by either treatment, LWR in $S$. planifolia was with $0.37 \mathrm{~g} \mathrm{~g}^{-1}$ lower at $5^{\circ} \mathrm{C}$ compared with $0.44 \mathrm{~g} \mathrm{~g}^{-1}$ at 10 and $20^{\circ} \mathrm{C}(p=0.006)$ (Fig. 2).

Total aboveground dry mass in $C$. canadensis was much higher than in the other two species during the eight-week growth period. Aboveground dry mass per plant was 21, 2.0 and $1.2 \mathrm{~g}$ for $C$. canadensis, S. planifolia, and A. crispa, respectively. Aboveground dry mass increased with increasing soil temperature in all three species. Aboveground dry mass of $S$. planifolia was not affected by water table at all three soil temperatures while in the other two species a water table effect was detectable at $20{ }^{\circ} \mathrm{C}$. While A. crispa seedlings had higher dry mass at the low water table compared with the high 
Water table

Soil temperature

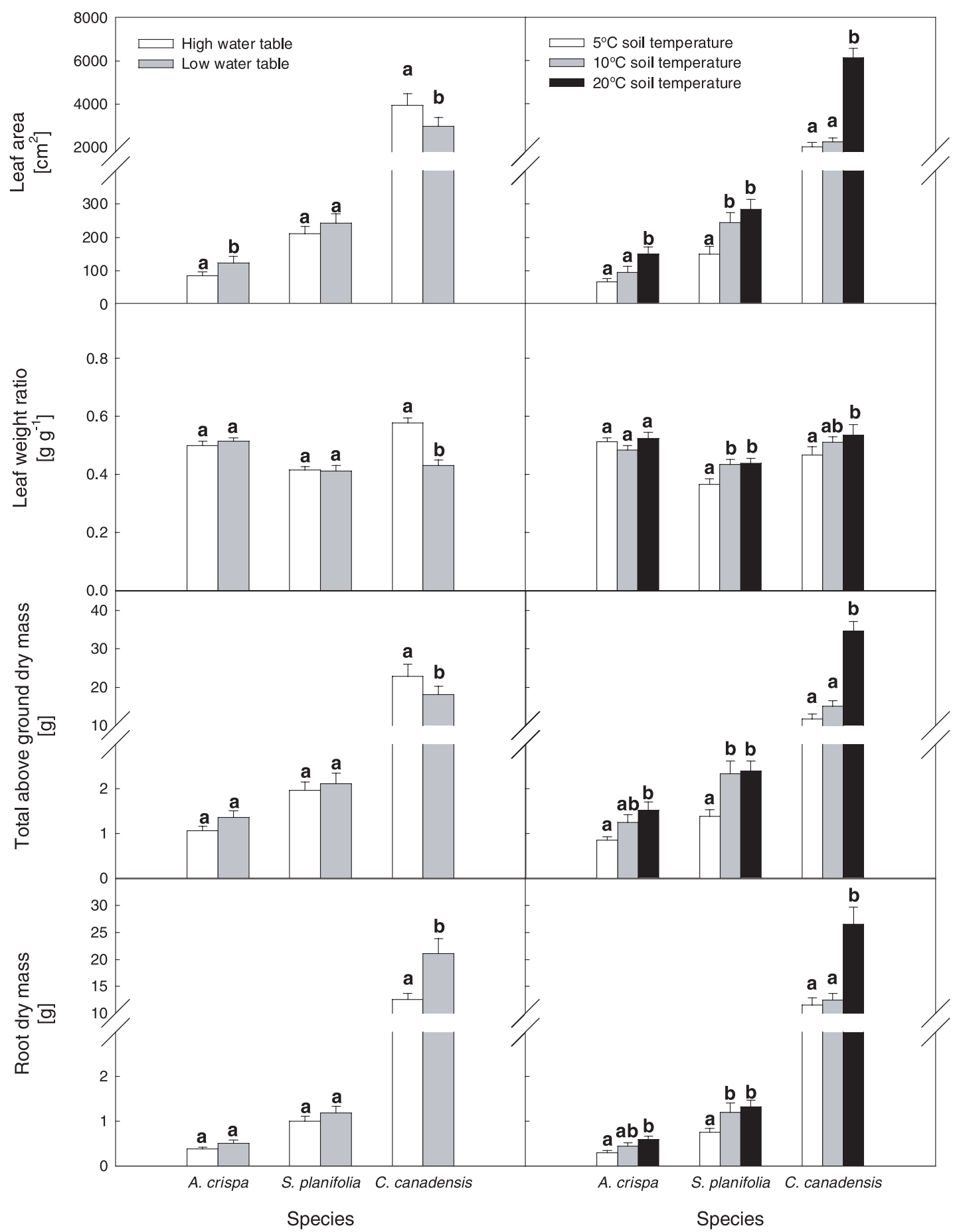

Figure 2. Leaf area, leaf weight ratio and above and below ground biomass of Alnus crispa, Salix planifolia and Calamagrostis canadensis grown at low water table height (imperfectly drained) and high water table (nearly flooded) and at 5,10 and $20^{\circ} \mathrm{C}$ soil temperatures $(n=7)$. Air temperature was $20^{\circ} \mathrm{C}$. Different letters indicate differences among treatment means within a species.

water table, C. canadensis showed the opposite response. This resulted in significant soil temperature $\times$ water table interactions for both A. crispa $(p=0.028)$ and $C$. canadensis $(p=0.026)$ (Fig. 2). Similarly, root dry mass in C. canadensis was much higher than in the other species after the eight-week growth period. Root dry mass was $0.44,1.1$, and $16.8 \mathrm{~g}$ for A. crispa, S. planifolia and C. canadensis, respectively. Generally, all three species had significantly larger root mass at the 
warmer soil temperatures. Only $C$. canadensis showed a response of root mass to water table height $(p<0.001)$. Root mass almost doubled from $12.6 \mathrm{~g}$ at the high water table to $21.1 \mathrm{~g}$ at the low water table (Fig. 2).

\section{DISCUSSION}

In terms of a hydrological nurse species, the data from this study, and the literature describing the aggressive colonization of newly disturbed areas by $C$. canadensis $[1,8,11]$ suggests that this grass with its rapid development of leaf area and relative high transpiration rates in nearly flooded conditions, could be effective in lowering the water table on very wet sites. However, since the rates of water use and growth in $C$. canadensis were much lower at the cold soil temperature compared with the warm soil temperatures, the importance of the grass in the reduction of the water table is likely to decline as soil temperatures of the site decrease, due to the accumulation of it's own insulating litter [20,32].

In this study, soil temperature was found to be an overriding factor in the physiology (including water use) and growth of all three species, while the effect of water table position was relatively weak. This weak response to water table might be the result of both water tables producing poorly drained soil conditions. This is corroborated by the $\mathrm{O}_{2}$ diffusion rates in the soil. While the imperfectly drained treatment had $14.2 \times$ $10^{-8} \mathrm{~g} \mathrm{O}_{2} \mathrm{~cm}^{-2} \mathrm{~min}^{-1}$ about 4.5 times higher diffusion than the near flooding treatment, the rates of $\mathrm{O}_{2}$ diffusion were still relatively low compared to published values of up to $25 \times 10^{-8} \mathrm{~g}$ $\mathrm{O}_{2} \mathrm{~cm}^{-2} \mathrm{~min}^{-1}$ for an organic soil under more drained conditions [38, 39]. The species tested in this experiment were all relatively well adapted to the poorly drained conditions as all three of these species are often naturally found in subhygric to hygric sites. The lower oxygen diffusion rates measured in $C$. canadensis likely relates to the large belowground biomass of roots and rhizomes relative to the more slowly growing shrubs. This actively growing biomass would have high $\mathrm{O}_{2}$ demands and in addition would occupy much of the soil pore space and thereby limiting $\mathrm{O}_{2}$ diffusion.

The two shrub species ( $S$. planifolia and A. crispa) showed much slower rates of growth and leaf area development in the first year. Given that they are woody perennials; however, we expect extensive leaf area development after five or more years. At this age it is not completely clear which shrub species would be the better hydrological nurse species. Alnus crispa had greater use of water on a whole pot basis in the high water table treatment, while it was the reverse for S. planifolia; however, S. planifolia was able to maintain its transpiration and photosynthesis rates at the cold soil temperatures compared with A. crispa. As soil temperatures of $10^{\circ} \mathrm{C}$ or less are likely on these sites, especially under a thick thatch of $C$. canadensis litter, $S$. planifolia is likely to have the greatest effect on high post-harvesting water tables. Given that the shrubs are taller than the grass, their shading is likely to suppress the growth of the grass [43] at this stage of stand development. This and the lower water tables will likely make the site more suitable for the establishment and growth of small spruce seedlings [16].
The mechanisms for increased tolerance to high water table in C. canadensis is likely related to the development of aerenchyma tissues in the rhizome and roots which has been observed in many flooding adapted species [28, 50]. This allows for the aeration of the roots of this species. The results of this study indicate that $S$. planifolia was physiologically adapted to respond favourably to a slightly lower water table. A similar response has been observed in Salix viminalis L. which showed a marked tolerance to flooded soil conditions and responded with vigorous root development to improved soil $\mathrm{O}_{2}$ [23]. In addition to the flooding tolerance, it is apparent that $S$. planifolia must have some unexplained mechanism which allows for high uptake of water by its roots at cold soil conditions. This is in contrast to species of Populus that have severely reduced water uptake at low soil temperatures [29, 31].

Low transpiration rates have been found in plants grown at cold soil temperatures $[7,25,33,57,59]$ which suggests that roots are slow to take up water when cold. While high viscosity of water and reduced permeability of roots are known to slow root water uptake at cold soil temperatures (e.g. [16, 18, 25]), Landhäusser et al. [33] speculate that other factors such as cell metabolism and membrane properties may also be affected. For $P$. tremuloides, Wan et al. [58] demonstrated that water channel proteins are important for water uptake.

Our study suggests that early colonization by $C$. canadensis followed by replacement with shrubs, especially $S$. planifolia may be a useful means of lowering water table on subhygric to hygric sites. A delay in planting $P$. glauca until the shrubs are well established might be considered as a low cost means of reforesting these sites. These nurse species, however, might also be considered as part of the current silvicultural practices for these wet northern sites, where mounding or plowing is used to produce elevated planting spots [2, 30, 49]. The mineral soil cap of mounds or berms, because of its high soil density and decreased moisture content, acts as an impediment for growth of $C$. canadensis rhizomes [30, 34, 47]. If a broadspectrum herbicide were also applied to kill the grass and the developing shrubs there would be a significant decrease in site evapotranspiration and the water table would remain high. On particularly wet sites, this might confine the roots of the $P$. glauca to the elevated spots leading to reduced tree growth. If roots are confined to the mounds it is likely to promote instability of trees $[51,52]$ as they grow in height. Thus, leaving grass or tall shrubs between the planting positions will likely improve the conditions for the roots as they explore soil layers beyond the mound. On subhygric to hygric sites, the benefits of reduced water table level when these associated species are present must be weighed against the competition effect of the grass and shrubs on the survival and growth of the planted $P$. glauca. This is a classic example of a trade-off that must be considered when using nurse species [10].

Acknowledgements: We thank Wei Liu and Caroline Huston for their assistance in running the experiment, sampling and measurements. Funding for this project was generously provided by Weldwood of Canada and Weyerhaeuser Canada Ltd. and was matched by Natural Sciences and Engineering Research Council of Canada (NSERC). 


\section{REFERENCES}

[1] Ahlgren C.E., Some effects of fire on reproduction and growth of vegetation in northeastern Minnesota, Ecology 41 (1960) 431-445.

[2] Bedford L., Sutton R.F., Stordeur L., Grismer M., Establishing white spruce in the Boreal White and Black Spruce zone - Site preparation trials at Wonowon and Iron Creek, British Columbia, New For. 20 (2000) 213-233.

[3] Bonan G.B., Soil temperature as an ecological factor in boreal forests, in: Shugart H.H., Leemans R., Bonan G.B. (Eds.), System analysis of the global boreal forest, Cambridge Press, Cambridge, 1992, pp. 126-143.

[4] Callaway R.M., King L., Temperature-driven variation in substrate oxygenation and the balance of competition and facilitation, Ecology 77 (1996) 1189-1195.

[5] Cole E., Youngblood A., Newton M., Effects of competing vegetation on juvenile white spruce (Picea glauca (Moench) Voss) growth in Alaska, Ann. For. Sci. 60 (2003) 573-583.

[6] Conlin T.S.S., Lieffers V.J., Root respiration of boreal forest conifers under anoxia and cool conditions, Can. J. For. Res. 23 (1992) 767-771.

[7] DeLucia E.H., Effects of low root temperature on net photosynthesis, stomatal conductance and carbohydrate concentration in Engelmann spruce (Picea engelmannii Parry ex Engelm.) seedlings, Tree Physiol. 2 (1986) 527-533.

[8] Drew T.J., Managing white spruce in Alberta's mixed-wood forest: the dilemma, in: Samoil J.K. (Ed.), Management and utilization of northern mixed woods, Report NOR-X-296, Can. For. Serv., North. For. Centre, Edmonton, Alberta, 1988, pp. 35-40.

[9] Dubé S., Plamondon A.P., Rothwell R.L., Watering up after clearcutting on forested wetlands of the St. Lawrence lowland, Water Resource Res. 31 (1995) 1741-1750.

[10] Dulohery C.J., Kolka R.K., McKevlin M.R., Effects of a willow overstory on planted seedlings in a bottomland restoration, Ecol. Engin. 15 (2000) S57-S66.

[11] Dyrness C.T., Norum R.A., The effects of experimental fires on black spruce forest floors in interior Alaska, Can. J. For. Res. 13 (1983) 879-893.

[12] Eis S., Establishment and early development of white spruce in the interior of British Columbia, For. Chron. 43 (1967) 174-177.

[13] Eis S., Effects of vegetation competition on revegetation of white spruce, Can. J. For. Res. 11 (1981) 1-8.

[14] Folk R.S., Grossnickle S.C., Russel J.H., Gas exchange, water relations and morphology of yellow-cedar seedlings and stockings before planting and during field establishment, New For. 9 (1995) $1-20$.

[15] Grossnickle S.C., Influence of flooding and soil temperature on the water relations and morphological development of cold-stored black spruce and white spruce seedlings, Can. J. For. Res. 17 (1987) 821-828.

[16] Grossnickle S.C., Ecophysiology of northern spruce species: The performance of planted seedlings, NRC Research Press, Ottawa, 2000.

[17] Grossnickle S.C., Blake T.J., Acclimation of cold-stored jack pine and white spruce seedlings: effect of soil temperature on water relations, Can. J. For. Res. 15 (1985) 544-550.

[18] Häussling C.A., Jorn CA., Lehmbecker G., Hecht-Buchholz C., Marschner H., Ion and water uptake in relation to root development in Norway spruce (Picea abies), J. Plant Physiol. 13 (1988) 486491.

[19] Heikurainen L., Effects of cutting on the ground water level on drained peatlands, in: Sopper W.E., Corbett E.S. (Eds.), International symposium on forest hydrology, Pergamon, Tarrytown, 1967, pp. 345-354.

[20] Hogg E.H., Lieffers V.J., The impact of Calamagrostis canadensis on soil thermal regimes after logging in northern Alberta, Can. J. For. Res. 21 (1991) 387-394.

[21] Hornung M., Newson M., Upland afforestation: influences on stream hydrology and chemistry, Soil Use Manage. 2 (1986) 61-65.
[22] Jackson M.B., Armstrong W., Formation of aerenchyma and the processes of plant ventilation in relation to soil flooding and submergence, Plant Biol. 1 (1999) 274-287.

[23] Jackson M.B., Attwood P.A., Roots of willow (Salix viminalis L.) show marked tolerance to oxygen shortage in flooded soils and in solution culture, Plant Soil 187 (1996) 37-45.

[24] Jobidon R., Roy V., Cyr G., Net effect of competing vegetation on selected environmental conditions and performance of four spruce seedling stock sizes after eight years in Québec (Canada), Ann. For. Sci. 60 (2003) 691-699.

[25] Kaufmann M.R., Leaf water stress in Engelmann spruce: Influence of the root and shoot environments, Plant Physiol. 56 (1975) 841844.

[26] Kozlowski T.T., Water supply and tree growth. Part II. Flooding, For. Abstr. 43 (1982) 145-161.

[27] Kozlowski T.T., Soil aeration and growth of forest trees, Scand. J. For. Res. 1 (1986) 113-123.

[28] Kozlowski T.T., Responses of woody plants to flooding and salinity, http://www.heronpublishing.com/tp/monograph/kozlowski.pdf, 1997.

[29] Landhäusser S.M., The effect of soil temperature on rooting and early establishment of Populus balsamifera cuttings, Tree Plant. Notes (to be published).

[30] Landhäusser S.M., Lieffers V.J., Rhizome growth of Calamagrostis canadensis into mounds created for tree seedling establishment, New For. 18 (1999) 245-262.

[31] Landhäusser S.M., Lieffers V.J., Growth of Populus tremuloides in association with Calamagrostis canadensis, Can. J. For. Res. 28 (1998) 396-401.

[32] Landhäusser S.M., Lieffers V.J., Competition between Calamagrostis canadensis and Epilobium angustifolium under different soil temperature and nutrient regimes, Can. J. For. Res. 24 (1994) 2244 2250.

[33] Landhäusser S.M., Desrochers A., Lieffers V.J., A comparison of growth and physiology in white spruce (Picea glauca) and aspen (Populus tremuloides) at different soil temperatures, Can. J. For. Res. 31 (2001) 1922-1929.

[34] Landhäusser S.M., Stadt K.J., Lieffers V.J., McNabb D., Rhizome growth of Calamagrostis canadensis in response to soil nutrients and bulk density, Can. J. Plant Sci. 76 (1996) 545-550.

[35] Landhäusser S.M., Wein R.W., Lange P., Gas exchange and growth of three arctic treeline tree species under different soil temperature and drought pre-conditioning regimes, Can. J. Bot. 74 (1996) 686693.

[36] Leder B., Zur Geschichte einer Einbeziehung von Weichlaubhölzern in die waldbauliche Praxis, Forst und Holz 48 (1993) 337-343.

[37] Leder B., Weichlaubhölzer in Eichen- und Buchen-Jungbeständen, Forst und Holz 51 (1996) 340-344.

[38] Lees J.C., Soil aeration and Sitka spruce seedling growth in peat, J. Ecol. 60 (1972) 343-349.

[39] Lees J.C., Soil aeration response to draining intensity in basin peat, Forestry 45 (1972) 135-143.

[40] Letey J., Stolzy L.H., Measurement of oxygen diffusion rates with the platinum microelectrode. I. Theory and equipment, Hilgardia 35 (1964) 545-554

[41] Levan M.A., Riha S.J., Response of root systems of northern conifer transplants to flooding, Can. J. For. Res. 16 (1986) 42-46.

[42] Lieffers V.J., Rothwell R.L., Effects of depth and water table and substrate temperature on root and top growth of Picea mariana and Larix laricina, Can. J. For. Res. 16 (1986) 1201-1206.

[43] Lieffers V.J., Stadt K.J., Growth of understory Picea glauca, Calamagrostis canadensis and Epilobium angustifolium in relation to overstory light transmission, Can. J. For. Res. 24 (1994) 1193-1198.

[44] Lieffers V.J., Macdonald S.E., Hogg E.H., Ecology of and control strategies for Calamagrostis canadensis in boreal in forest sites, Can. J. For. Res. 23 (1993) 2070-2077.

[45] Man R., Lieffers V.J., Photosynthesis of Picea glauca and Pinus banksiana in relation to season and temperature, Can. J. Bot. 75 (1997) 1766-1771. 
[46] McIntyre D.S., The platinum microelectrode method for soil aeration measurement, Adv. Agron. 22 (1970) 235-283.

[47] McMinn R.G., Mechanical site preparation in forest vegetation management: A research synthesis, in: Harrington T.B., Parendes L.A. (Eds.), Forest vegetation management without herbicides, Proc. Feb 1992, College of Forestry, O.S.U, Oregon, 1993, pp. 39-43.

[48] Neilson R.E., Jarvis P.G., Photosynthesis in Sitka spruce (Picea sitchensis (Bong.) Carr.). IV. Response of stomata to temperature, J. Appl. Ecol. 12 (1976) 879-891.

[49] Örlander G., Gemmel P., Hunt J., Site preparation: a Swedish overview. FRDA Rep. 105. B.C. Min. For. Lands, Victoria, 1990.

[50] Pereira J.S., Kozlowski T.T., Variations among woody angiosperms in response to flooding, Physiol. Plant. 41 (1977) 184-192.

[51] Quine C.P., Burnand A.C., Coutts M.P., Reynard B.R., Effects of mounds and stumps on the root architecture of Sitka spruce on a peaty gley restocking site, Forestry 64 (1991) 385-401.

[52] Ray D., Nicoll B.C., The effect of soil water-table depth on rootplate development and stability of Sitka spruce, Forestry 71 (1998) 169-182.
[53] Schmidt-Schütz A., Wiederbewaldung von Fichten-Sturmwurfflächen aud vernässenden Standorten mit Hilfe von Pioniergehölzen Forst. Forschungsber. 176 (1999) 120-130.

[54] Tryon P.R., Chapin F.S., Temperature control over root growth and biomass in taiga forest trees, Can. J. For. Res. 13 (1983) 827-833.

[55] Vapaavuori E.M., Rikala R., Ryyppö A., Effects of root temperature on growth and photosynthesis in conifer seedlings during shoot elongation, Tree Physiol. 10 (1992) 217-230.

[56] Vartapetian B.B., Jackson M.B. Plant adaptations to anaerobic stress, Ann. Bot. 79 (1997) 3-20 Suppl. A.

[57] Wan X., Zwiazek J.J., Mercuric Chloride effects on root water transport in aspen seedlings, Plant Physiol. 121 (1999) 939-946.

[58] Wan X., Zwiazek J.J., Lieffers V.J., Landhäusser S.M., Hydraulic conductance in aspen (Populus tremuloides) seedlings exposed to low soil temperatures, Tree Physiol. 21 (2001) 691-696.

[59] Wan X., Landhäusser S.M., Zwiazek J.J., Lieffers V.J., Root water flow and growth of aspen (Populus tremuloides) at low root temperatures, Tree Physiol. 19 (1999) 879-884.

[60] Zasada J.C., Viereck L.A., Foote M.J., Parkenson R.H., Wolff J.O., Lankford L.A., Natural regeneration of Balsam Poplar following harvesting in the Susitna Valley, Alaska, For. Chron. 57 (1981) 57-65. 